\title{
Dysfunction and Therapeutic Potential of Endothelial Progenitor Cells in Diabetes Mellitus
}

\author{
Lidong $\mathrm{Hu}^{\mathrm{a}}$, Si-Cheng Dai ${ }^{\mathrm{b}, \mathrm{c}}$, Xiaojun Luan ${ }^{\mathrm{a}, \mathrm{d}}$, Jingsong Chen ${ }^{\mathrm{a}}$, \\ Anthony Cannavicci ${ }^{\mathrm{c}}$
}

\begin{abstract}
Diabetes mellitus (DM) is a chronic, multifactorial metabolic disease whereby insulin deficiency or resistance results in hyperglycemia. Endothelial cells (ECs) form the innermost layer of the blood vessel and produce and release a variety of vasoactive substances and growth factors to regulate vascular homeostasis and angiogenesis. Hyperglycemia and insulin resistance can cause endothelial dysfunction, leading to vascular complications such as coronary artery disease, peripheral arterial disease, diabetic nephropathy, neuropathy and retinopathy. The detrimental effect exerted on ECs by hyperglycemia and insulin resistance underlines the importance of reparatory mechanisms in DM. Endothelial progenitor cells (EPCs), derived from bone marrow, have been recognized as endogenous cells involved in endothelial repair and new blood vessel formation. Initially isolated from a subset of circulating CD34+ mononuclear cells, EPCs were found to possess the ability to differentiate into ECs when cultured in vitro and incorporate into newly formed vessels upon transplantation in animal models of ischemia. Due to the low frequency of CD34+ cells in circulation, the vast majority of studies investigating EPC actions have used cells that are generated through the culture of peripheral blood mononuclear cells (PBMNCs) for 4 - 7 days in endothelial selective medium. These cells, mainly of myeloid hematopoietic cell origin, were termed "Early EPCs," of which, few expressed stem/progenitor-cell markers. Therefore, early EPCs were also termed "myeloid angiogenic cells" (MACs). When PBMNCs are cultured for over 2 weeks, early EPCs gradually diminish while socalled late EPCs appear. Late EPCs share phenotypic features with mature ECs and are therefore also termed blood-derived ECs; they will not be addressed in this review. MAC dysfunction has been observed in a variety of disease conditions including DM. In this article we review the activities and therapeutic potential of MACs in DM. We will interchangeably use "EPCs" and "MACs" to refer to the cells
\end{abstract}

Manuscript submitted August 5, 2018, accepted August 16, 2018

aDepartment of Endocrinology, The First People's Hospital of Foshan, Foshan 528000, Guangdong, China

bMedical Sciences Program, Western University, London, ON, Canada

'Keenan Research Center for Biomedical Science, St. Michael's Hospital, University of Toronto, Toronto, ON, Canada

${ }^{\mathrm{d} C}$ Corresponding Author: Xiaojun Luan, Department of Endocrinology, The First People's Hospital of Foshan, No 81 Lingnan Avenue North, Chancheng District, Foshan 528000, Guangdong, China. Email: Drxiaojun@yahoo.com

doi: https://doi.org/10.14740/jocmr3581w procured by culture of PBMNCs in EC selective medium for approximately 7 days.

Keywords: Diabetes mellitus; Endothelial dysfunction; Endothelial progenitor cell; Myeloid angiogenic cell; Angiogenesis; Cell therapy

\section{Introduction}

Diabetes mellitus (DM) is a chronic, multifactorial metabolic disorder and a major cause of blindness, kidney failure, heart attacks, stroke and lower limb amputation [1]. According to the data released in 2017 by the World Health Organization, DM affected 422 million people worldwide in 2014 and will be the seventh leading cause of death in 2030 (http://www. who.int/news-room/fact-sheets/detail/diabetes). There are two types of DMs, i.e., type 1 and type 2. Type 1 diabetes is an autoimmune disorder whereby the body's own immune system attacks the $\beta$ cells of the pancreas, resulting in the death of $\beta$-cells and thereby little or no insulin production [2-5]; while type 2 diabetes, which is more common, is caused by insulin resistance along with the impaired secretion of insulin [6-11]. Both types of DM are characterized by hyperglycemia that can cause microvascular complications, e.g., diabetic nephropathy, neuropathy and retinopathy; and macrovascular complications, e.g., coronary artery disease, peripheral arterial disease and cerebrovascular disease [1].

Endothelial cells (ECs) form the innermost layer of the blood vessel and regulate vascular homeostasis and angiogenesis through the production and secretion of a variety of vasoactive substances and growth factors $[12,13]$. One such molecule is nitric oxide (NO), a vasodilator that plays an important role in controlling blood vessel tone [14, 15]. Other activities of NO include suppressing platelet adhesion and aggregation (preventing thrombosis) [16-19], promoting angiogenesis [2025], and inhibiting vascular inflammation [26-28]. It has been well documented that hyperglycemia and insulin resistance negatively impact the production of bioavailable NO from the endothelium, resulting in increased vasoconstriction, vessel stiffness, platelet aggregation and impaired angiogenesis [2932]. Evidence also indicates that hyperglycemia induces EC apoptosis and subsequent arterial denudation, promoting atherosclerotic processes [33-35]. Additionally, hyperglycemia can cause oxidative stress in ECs [35-37]. All these detrimen- 
tal effects exerted by hyperglycemia on the endothelium underline the importance of reparatory mechanisms in DM [38]. Endothelial progenitor cells (EPCs), derived from bone marrow, have been recognized as endogenous cells contributing to endothelial repair and angiogenesis [39-41]. In this article, we review the activities and therapeutic potential of EPCs in DM.

\section{Endothelial Progenitor Cells}

EPCs, identified two decades ago as a subset of circulating CD34+ mononuclear cells, possess the ability to differentiate into ECs when cultured in vitro and incorporate into newly formed vessels upon transplantation in animal models of ischemia [39]. Since the discovery of EPCs, EPC research has been evolving rapidly, with most efforts being made in the investigation of EPCs as biomarkers for diseases and novel therapeutic tools for angiogenesis and injury repair [42-47]. CD34+ mononuclear cells have a very low frequency (400/ $\mathrm{mL}$ of blood) in circulation [48], making it difficult to obtain sufficient EPCs from CD34+ mononuclear cells for therapeutic applications. Therefore, most studies, including preclinical animal works and clinical trials, have used EPCs procured through the culture of peripheral blood mononuclear cells (PBMNCs) for 4 - 7 days in endothelial selective medium containing vascular endothelial growth factor [46, 47, 49]. These cells, originally referred to as early EPCs, constitute a heterogeneous population that originates mainly from myeloid hematopoietic cells [50-52], and have been shown to promote angiogenesis and vascular repair in various experimental settings. However, further research demonstrated that few early EPCs expressed stem/progenitor-cell markers [53, 54]. These early EPCs did not directly give rise to new blood vessels either; instead, these cells promoted angiogenesis through the production and secretion of a variety of paracrine factors such as VEGF, HGF, IL-8, eNOS, etc., making it controversial to name these cells "EPCs." Therefore, the term "circulating angiogenic cells" (CACs) was suggested $[49,53]$. More recently, Medina et al argued that there is insufficient proof to verify the "circulating" status of CACs in vivo, and multiple lines of evidence indicate that CACs might be generated in vitro due to cell culture conditions that do not exist in vivo. They therefore recommended the term "myeloid angiogenic cells" (MACs) for these cells according to both their lineage and function [55]. When PBMNCs are cultured for over 2 weeks, early EPCs gradually diminish while so-called late EPCs appear. Late EPCs share phenotypic features with mature ECs, and therefore are also termed blood-derived ECs [55]; however, they will not be the focus of this article. In this review, "EPCs" and "MACs" will be interchangeably used in reference to the cells generated by the culture of PBMNCs in EC selective medium for approximately 7 days.

\section{Endothelial Progenitor Cell Dysfunction in Dia- betes Mellitus}

A variety of disease conditions including DM negatively affect
EPCs [56-66]. Hyperglycemia induced reduction of EPCs has been shown in many studies [58-66]. Tepper et al compared activity of EPCs isolated from patients with type 2 diabetes to age-matched healthy controls and found that proliferation of diabetic EPCs was dramatically decreased [58]. Loomans et al reported that EPCs isolated from patients with type 1 diabetes displayed $80 \%$ positivity in the uptake of DiI-labeled acLDL, the binding of the lectin UEA-1, and the expression of the CD31 antigen. Although these markers were highly expressed, a significantly lower number of EPCs were generated from the same volume of blood in patients compared with healthy controls; additionally, the number of EPCs was negatively associated with HbAlc levels [59]. In the culture of EPCs isolated from healthy donors, high glucose can significantly reduce not only the number of DiI-acLDL/lectin UEA-1 double positive EPCs, but also the number of EPCs expressing VEGF receptor-2 and CD31 [60]. Reduction of EPCs in patients with type 2 diabetes was also observed in other studies [61-63]. In a murine model of diabetes, suppressed release of plasma VEGF and stromal cell-derived factor-1 (SDF-1), two key cytokines that stimulate EPC mobilization from bone marrow, was found to be related to the reduction of EPCs [64]. Insulin treatment can substantially elevate plasma VEGF and SDF-1 levels, this effect however, can be blunted by L-NAME [64], indicating that hyperglycemia reduces EPC numbers through the inhibition of VEGF and SDF-1, which is dependent on NO, an essential factor controlling the mobilization of stem and progenitor cells [67]. It is known that high glucose results in less production of NO in EPCs $[57,65,66]$. When EPCs isolated from healthy individuals are cultured in the presence of a high concentration of glucose, they undergo a higher rate of apoptosis $[60,65,66]$. Seemingly, hyperglycemia induces a proapoptotic property in EPCs, a contributing factor to the EPC reduction seen in patients with diabetes $[65,66]$. Of note, no evidence for increased apoptosis in cultured EPCs from type 1 diabetic patients has been observed [59]. Matrix metalloproteinase-9 (MMP-9) is required for stem cell and progenitor cell mobilization [67], and EPCs from healthy subjects express less MMP-9 when cultured in medium containing high glucose compared with control medium [65].

Various aspects of EPC function in patients with diabetes are impaired, e.g., cell adhesion, cell migration and cell incorporation into vascular structures. EPC adhesion to collagen, fibronectin and human umbilical vein endothelial cells (HUVECs) was impeded in type 2 diabetes patients [58]. Wang et al revealed that EPCs from diabetes patients had reduced adhesion to matrix molecules (collagen and fibronectin) and suppressed migration towards VEGF, which were significantly improved after 2-month treatment with pioglitazone [63]. Using the modified Boyden chamber cell migration assay, Thum et al found that EPCs from diabetic patients exhibited impaired directional migration towards both VEGF and SDF-1 compared with EPCs from nondiabetic age-matched subjects [62]. The impaired cell migration towards VEGF could possibly be due to the decreased expression of VEGF receptor 2 in EPCs from patients [60]. Additionally, EPCs from patients with diabetes exhibit increased reactive oxygen species (ROS) formation, which might also be responsible for inhibited cell migration as pegylated superoxide dismutase, a free radical 
scavenger, can abrogate glucose-mediated impairment of EPC migration [62]. It has been shown that culture of EPCs from healthy individuals in hyperglycemic medium leads to a decrease in eNOS phosphorylation and thereby diminished NO, which is associated with the impaired cell migration. This effect can be blocked in part by okadaic acid, a potent inhibitor of protein phosphatases, suggesting that suppression of EPC migration by high glucose is mediated by the decrease in NO production [65]. The role of $\mathrm{NO}$ in regulating diabetic EPC migration is also supported by another study showing that the EPC migratory defect associated with diabetes could be corrected after incubation of EPCs with NO [68].

Using the tubule formation assay, several groups have demonstrated that hyperglycemia results in EPC angiogenic dysfunction. HUVECs seeded on the matrix protein gel form capillary-like structures, which can be significantly enhanced by the addition of the condition medium from healthy EPC cultures, suggesting that EPCs promote angiogenesis through a paracrine pathway. In contrast, this effect is absent if the condition medium from diabetic EPC cultures was supplied [59]. Microarray analyses showed differential gene expression in patient-derived cultured EPCs compared with healthy EPCs, indicating that dysregulated gene expression might play a role in EPC dysfunction in patients [59]. Another study discovered that fewer EPCs from type 2 diabetes patients were incorporated into the tubule network compared with healthy EPCs when EPCs and human microvascular ECs were co-cultured within Matrigel [58]. Krankel et al demonstrated that when EPCs from healthy subjects were cultured under high glucose, their ability to incorporate into three-dimensional capillary structures of mature human coronary artery ECs was diminished by $50 \%$ as compared with EPCs cultured in control medium [65]. This incorporation defect is partly attributed to the reduced production of NO in EPCs exposed to high glucose [65]. In a recently published study, Chambers et al cultured MACs derived from healthy individuals in medium containing high or normal glucose, collected the condition medium and added it to human endothelial colony forming cells (ECFCs) grown in Matrigel, and observed a significant reduction in ECFC tubule formation in the cells receiving the high glucose conditioned medium [69]. Similar results were obtained when ECFCs were co-cultured with MACs that were previously exposed to high glucose [69]. These findings align well with the data presented by Loomans et al [59]. Gene expression analyses using RT-qPCR identified some important genes dysregulated by high glucose, namely the upregulation of proinflammatory transcripts IL1 $\beta$, IL6 and IL $1 \alpha$, and downregulation of proangiogenic and anti-inflammatory markers CD163 and CD204 [69]. The use of a neutralizing antibody against IL1 $\beta$ corrected high glucose induced dysfunction in MACs. Increased expression of IL $1 \beta$ in MACs isolated from patients with type 1 diabetes was also detected, suggesting that IL1 $\beta$ contributes to hyperglycemia-induced MAC dysfunction, and can be a potential therapeutic target for the restoration of MAC functionality in DM. Reendothelialization capacity of EPCs from diabetic patients has also been assessed in vivo. In a nude mouse model of carotid artery endothelial denudation, EPCs from individuals with type 2 diabetes or healthy controls were injected through the tail vein after the injury was created, revealing that reendothelialization capacity of EPCs from individuals with diabetes mellitus was severely impaired [70]. Further examination uncovered increased NADPH oxidase-dependent superoxide production and subsequently reduced NO bioavailability as the cause of compromised capacity in diabetic EPCs, and the peroxisome proliferator activated receptor- $\gamma$ agonist, i.e., rosiglitazone, as a rescuer of diabetic EPC function [70].

\section{Therapeutic Potential of Endothelial Progenitor Cells in Diabetes Mellitus}

EPCs boost angiogenesis and promote reendothelialization. Ischemic lesions and endothelial dysfunction are common in diabetes. Therefore, autologous EPC therapy could benefit patients with diabetes. However, as depicted above, multiple lines of evidence indicate that diabetic patients have a lower number of EPCs and impaired EPC function. Although clinical trials using EPCs for the treatment of ischemic heart disease and critical peripheral artery disease have been performed [71, 72], randomized and blinded clinical trials using autologous EPCs for the management of DM have not been reported. We believe that a clinical trial employing EPCs in DM treatment will not be carried out until methods that optimally improve DM EPCs are discovered.

\section{Conclusions}

EPC numbers are reduced and various aspects of EPC function are impaired in DM, not only reflecting the pathophysiological process of DM but also indicating that the therapeutic potential of DM EPCs is compromised. The optimal strategies to augment DM EPCs for therapeutic angiogenesis remain to be identified.

\section{Conflicts of Interest}

None.

\section{References}

1. American Diabetes Association. Diagnosis and classification of diabetes mellitus. Diabetes Care. 2014;37(Suppl 1):S81-90.

2. Katsarou A, Gudbjornsdottir S, Rawshani A, Dabelea D, Bonifacio E, Anderson BJ, Jacobsen LM, et al. Type 1 diabetes mellitus. Nat Rev Dis Primers. 2017;3:17016.

3. Babon JA, DeNicola ME, Blodgett DM, Crevecoeur I, Buttrick TS, Maehr R, Bottino R, et al. Analysis of selfantigen specificity of islet-infiltrating $\mathrm{T}$ cells from human donors with type 1 diabetes. Nat Med. 2016;22(12):14821487.

4. Marre ML, Profozich JL, Coneybeer JT, Geng X, Bertera $\mathrm{S}$, Ford MJ, Trucco M, et al. Inherent ER stress in pancre- 
atic islet beta cells causes self-recognition by autoreactive T cells in type 1 diabetes. J Autoimmun. 2016;72:33-46.

5. Noble JA. Immunogenetics of type 1 diabetes: A comprehensive review. J Autoimmun. 2015;64:101-112.

6. DeFronzo RA, Ferrannini E, Groop L, Henry RR, Herman WH, Holst JJ, Hu FB, et al. Type 2 diabetes mellitus. Nat Rev Dis Primers. 2015;1:15019.

7. Halban PA, Polonsky KS, Bowden DW, Hawkins MA, Ling C, Mather KJ, Powers AC, et al. beta-cell failure in type 2 diabetes: postulated mechanisms and prospects for prevention and treatment. J Clin Endocrinol Metab. 2014;99(6):1983-1992.

8. Martin BC, Warram JH, Krolewski AS, Bergman RN, Soeldner JS, Kahn CR. Role of glucose and insulin resistance in development of type 2 diabetes mellitus: results of a 25-year follow-up study. Lancet. 1992;340(8825):925929.

9. Ferrannini E, Mari A. beta-Cell function in type 2 diabetes. Metabolism. 2014;63(10):1217-1227.

10. Bensellam M, Laybutt DR, Jonas JC. The molecular mechanisms of pancreatic beta-cell glucotoxicity: recent findings and future research directions. Mol Cell Endocrinol. 2012;364(1-2):1-27.

11. Kulkarni RN, Bruning JC, Winnay JN, Postic C, Magnuson MA, Kahn CR. Tissue-specific knockout of the insulin receptor in pancreatic beta cells creates an insulin secretory defect similar to that in type 2 diabetes. Cell. 1999;96(3):329-339.

12. Michiels C. Endothelial cell functions. J Cell Physiol. 2003;196(3):430-443.

13. Pober JS, Sessa WC. Evolving functions of endothelial cells in inflammation. Nat Rev Immunol. 2007;7(10):803815.

14. Palmer RM, Ferrige AG, Moncada S. Nitric oxide release accounts for the biological activity of endothelium-derived relaxing factor. Nature. 1987;327(6122):524-526.

15. Tousoulis D, Kampoli AM, Tentolouris C, Papageorgiou $\mathrm{N}$, Stefanadis $\mathrm{C}$. The role of nitric oxide on endothelial function. Curr Vasc Pharmacol. 2012;10(1):4-18.

16. Radomski MW, Palmer RM, Moncada S. The role of nitric oxide and cGMP in platelet adhesion to vascular endothelium. Biochem Biophys Res Commun. 1987;148(3):1482-1489.

17. Radomski MW, Palmer RM, Moncada S. Endogenous nitric oxide inhibits human platelet adhesion to vascular endothelium. Lancet. 1987;2(8567):1057-1058.

18. Sneddon JM, Vane JR. Endothelium-derived relaxing factor reduces platelet adhesion to bovine endothelial cells. Proc Natl Acad Sci U S A. 1988;85(8):2800-2804.

19. Bassenge E. Antiplatelet effects of endothelium-derived relaxing factor and nitric oxide donors. Eur Heart J. 1991;12(Suppl E):12-15.

20. Ziche M, Morbidelli L, Masini E, Amerini S, Granger HJ, Maggi CA, Geppetti P, et al. Nitric oxide mediates angiogenesis in vivo and endothelial cell growth and migration in vitro promoted by substance P. J Clin Invest. 1994;94(5):2036-2044.

21. Papapetropoulos A, Garcia-Cardena G, Madri JA, Sessa WC. Nitric oxide production contributes to the angiogen- ic properties of vascular endothelial growth factor in human endothelial cells. J Clin Invest. 1997;100(12):31313139.

22. Babaei S, Teichert-Kuliszewska K, Monge JC, Mohamed F, Bendeck MP, Stewart DJ. Role of nitric oxide in the angiogenic response in vitro to basic fibroblast growth factor. Circ Res. 1998;82(9):1007-1015.

23. Murohara T, Asahara T, Silver M, Bauters C, Masuda H, Kalka C, Kearney M, et al. Nitric oxide synthase modulates angiogenesis in response to tissue ischemia. J Clin Invest. 1998;101(11):2567-2578.

24. Cooke JP, Losordo DW. Nitric oxide and angiogenesis. Circulation. 2002;105(18):2133-2135.

25. Morbidelli L, Donnini S, Ziche M. Role of nitric oxide in the modulation of angiogenesis. Curr Pharm Des. 2003;9(7):521-530.

26. De Caterina R, Libby P, Peng HB, Thannickal VJ, Rajavashisth TB, Gimbrone MA, Jr., Shin WS, et al. Nitric oxide decreases cytokine-induced endothelial activation. Nitric oxide selectively reduces endothelial expression of adhesion molecules and proinflammatory cytokines. J Clin Invest. 1995;96(1):60-68.

27. Granger DN, Kubes P. Nitric oxide as antiinflammatory agent. Methods Enzymol. 1996;269:434-442.

28. Momi S, Monopoli A, Alberti PF, Falcinelli E, Corazzi T, Conti V, Miglietta D, et al. Nitric oxide enhances the anti-inflammatory and anti-atherogenic activity of atorvastatin in a mouse model of accelerated atherosclerosis. Cardiovasc Res. 2012;94(3):428-438.

29. Kim JA, Montagnani M, Koh KK, Quon MJ. Reciprocal relationships between insulin resistance and endothelial dysfunction: molecular and pathophysiological mechanisms. Circulation. 2006;113(15):1888-1904.

30. Bakker W, Eringa EC, Sipkema P, van Hinsbergh VW. Endothelial dysfunction and diabetes: roles of hyperglycemia, impaired insulin signaling and obesity. Cell Tissue Res. 2009;335(1):165-189.

31. Calles-Escandon J, Cipolla M. Diabetes and endothelial dysfunction: a clinical perspective. Endocr Rev. 2001;22(1):36-52.

32. Tabit CE, Chung WB, Hamburg NM, Vita JA. Endothelial dysfunction in diabetes mellitus: molecular mechanisms and clinical implications. Rev Endocr Metab Disord. 2010;11(1):61-74.

33. Ido Y, Carling D, Ruderman N. Hyperglycemia-induced apoptosis in human umbilical vein endothelial cells: inhibition by the AMP-activated protein kinase activation. Diabetes. 2002;51(1):159-167.

34. Sheu ML, Ho FM, Yang RS, Chao KF, Lin WW, Lin-Shiau SY, Liu SH. High glucose induces human endothelial cell apoptosis through a phosphoinositide 3-kinase-regulated cyclooxygenase-2 pathway. Arterioscler Thromb Vasc Biol. 2005;25(3):539-545.

35. Wu N, Shen H, Liu H, Wang Y, Bai Y, Han P. Acute blood glucose fluctuation enhances rat aorta endothelial cell apoptosis, oxidative stress and pro-inflammatory cytokine expression in vivo. Cardiovasc Diabetol. 2016;15(1):109.

36. Ceriello A, Taboga C, Tonutti L, Quagliaro L, Piconi L, Bais B, Da Ros R, et al. Evidence for an independent and 
cumulative effect of postprandial hypertriglyceridemia and hyperglycemia on endothelial dysfunction and oxidative stress generation: effects of short- and long-term simvastatin treatment. Circulation. 2002;106(10):1211-1218.

37. Fiorentino TV, Prioletta A, Zuo P, Folli F. Hyperglycemia-induced oxidative stress and its role in diabetes mellitus related cardiovascular diseases. Curr Pharm Des. 2013;19(32):5695-5703.

38. Avogaro A, Albiero M, Menegazzo L, de Kreutzenberg S, Fadini GP. Endothelial dysfunction in diabetes: the role of reparatory mechanisms. Diabetes Care. 2011;34(Suppl 2):S285-290.

39. Asahara T, Murohara T, Sullivan A, Silver M, van der Zee R, Li T, Witzenbichler B, et al. Isolation of putative progenitor endothelial cells for angiogenesis. Science. 1997;275(5302):964-967.

40. Shi Q, Rafii S, Wu MH, Wijelath ES, Yu C, Ishida A, Fujita $\mathrm{Y}$, et al. Evidence for circulating bone marrow-derived endothelial cells. Blood. 1998;92(2):362-367.

41. Asahara T, Masuda H, Takahashi T, Kalka C, Pastore C, Silver M, Kearne M, et al. Bone marrow origin of endothelial progenitor cells responsible for postnatal vasculogenesis in physiological and pathological neovascularization. Circ Res. 1999;85(3):221-228.

42. Vasa M, Fichtlscherer S, Aicher A, Adler K, Urbich C, Martin H, Zeiher AM, et al. Number and migratory activity of circulating endothelial progenitor cells inversely correlate with risk factors for coronary artery disease. Circ Res. 2001;89(1):E1-7.

43. Choi JH, Kim KL, Huh W, Kim B, Byun J, Suh W, Sung $\mathrm{J}$, et al. Decreased number and impaired angiogenic function of endothelial progenitor cells in patients with chronic renal failure. Arterioscler Thromb Vasc Biol. 2004;24(7):1246-1252.

44. Lee ST, Chu K, Jung KH, Kim DH, Kim EH, Choe VN, $\mathrm{Kim} \mathrm{JH}$, et al. Decreased number and function of endothelial progenitor cells in patients with migraine. Neurology. 2008;70(17):1510-1517.

45. Takahashi T, Kalka C, Masuda H, Chen D, Silver M, Kearney M, Magner M, et al. Ischemia- and cytokineinduced mobilization of bone marrow-derived endothelial progenitor cells for neovascularization. Nat Med. 1999;5(4):434-438.

46. Kalka C, Masuda H, Takahashi T, Kalka-Moll WM, Silver M, Kearney M, Li T, et al. Transplantation of ex vivo expanded endothelial progenitor cells for therapeutic neovascularization. Proc Natl Acad Sci U S A. 2000;97(7):3422-3427.

47. Ward MR, Thompson KA, Isaac K, Vecchiarelli J, Zhang Q, Stewart DJ, Kutryk MJ. Nitric oxide synthase gene transfer restores activity of circulating angiogenic cells from patients with coronary artery disease. Mol Ther. 2011;19(7):1323-1330.

48. Asosingh K, Aldred MA, Vasanji A, Drazba J, Sharp J, Farver C, Comhair SA, et al. Circulating angiogenic precursors in idiopathic pulmonary arterial hypertension. Am J Pathol. 2008;172(3):615-627.

49. Fadini GP, Losordo D, Dimmeler S. Critical reevaluation of endothelial progenitor cell phenotypes for therapeutic and diagnostic use. Circ Res. 2012;110(4):624-637.

50. Urbich C, Heeschen C, Aicher A, Dernbach E, Zeiher AM, Dimmeler S. Relevance of monocytic features for neovascularization capacity of circulating endothelial progenitor cells. Circulation. 2003;108(20):2511-2516.

51. Rehman J, Li J, Orschell CM, March KL. Peripheral blood "endothelial progenitor cells" are derived from monocyte/macrophages and secrete angiogenic growth factors. Circulation. 2003;107(8):1164-1169.

52. Rohde E, Malischnik C, Thaler D, Maierhofer T, Linkesch W, Lanzer G, Guelly C, et al. Blood monocytes mimic endothelial progenitor cells. Stem Cells. 2006;24(2):357367.

53. Rehman J, Li J, Parvathaneni L, Karlsson G, Panchal VR, Temm CJ, Mahenthiran J, et al. Exercise acutely increases circulating endothelial progenitor cells and monocyte-/ macrophage-derived angiogenic cells. J Am Coll Cardiol. 2004;43(12):2314-2318.

54. Lopez-Holgado N, Alberca M, Sanchez-Guijo F, Villaron E, Almeida J, Martin A, Armellini A, et al. Short-term endothelial progenitor cell colonies are composed of monocytes and do not acquire endothelial markers. Cytotherapy. 2007;9(1):14-22.

55. Medina RJ, Barber CL, Sabatier F, Dignat-George F, Melero-Martin JM, Khosrotehrani K, Ohneda O, et al. Endothelial progenitors: a consensus statement on nomenclature. Stem Cells Transl Med. 2017;6(5):1316-1320.

56. Hill JM, Zalos G, Halcox JP, Schenke WH, Waclawiw MA, Quyyumi AA, Finkel T. Circulating endothelial progenitor cells, vascular function, and cardiovascular risk. N Engl J Med. 2003;348(7):593-600.

57. Menegazzo L, Albiero M, Avogaro A, Fadini GP. Endothelial progenitor cells in diabetes mellitus. Biofactors. 2012;38(3):194-202.

58. Tepper OM, Galiano RD, Capla JM, Kalka C, Gagne PJ, Jacobowitz GR, Levine JP, et al. Human endothelial progenitor cells from type II diabetics exhibit impaired proliferation, adhesion, and incorporation into vascular structures. Circulation. 2002;106(22):2781-2786.

59. Loomans CJ, de Koning EJ, Staal FJ, Rookmaaker MB, Verseyden C, de Boer HC, Verhaar MC, et al. Endothelial progenitor cell dysfunction: a novel concept in the pathogenesis of vascular complications of type 1 diabetes. Diabetes. 2004;53(1):195-199.

60. Marchetti V, Menghini R, Rizza S, Vivanti A, Feccia T, Lauro D, Fukamizu A, et al. Benfotiamine counteracts glucose toxicity effects on endothelial progenitor cell differentiation via Akt/FoxO signaling. Diabetes. 2006;55(8):2231-2237.

61. van Ark J, Moser J, Lexis CP, Bekkema F, Pop I, van der Horst IC, Zeebregts CJ, et al. Type 2 diabetes mellitus is associated with an imbalance in circulating endothelial and smooth muscle progenitor cell numbers. Diabetologia. 2012;55(9):2501-2512.

62. Thum T, Fraccarollo D, Schultheiss M, Froese S, Galuppo P, Widder JD, Tsikas D, et al. Endothelial nitric oxide synthase uncoupling impairs endothelial progenitor cell mobilization and function in diabetes. Diabetes. 2007;56(3):666-674. 
63. Wang CH, Ting MK, Verma S, Kuo LT, Yang NI, Hsieh IC, Wang SY, et al. Pioglitazone increases the numbers and improves the functional capacity of endothelial progenitor cells in patients with diabetes mellitus. Am Heart J. 2006;152(6):1051 e1051-1058.

64. Dong L, Kang L, Ding L, Chen Q, Bai J, Gu R, Li L, et al. Insulin modulates ischemia-induced endothelial progenitor cell mobilization and neovascularization in diabetic mice. Microvasc Res. 2011;82(3):227-236.

65. Krankel N, Adams V, Linke A, Gielen S, Erbs S, Lenk $\mathrm{K}$, Schuler G, et al. Hyperglycemia reduces survival and impairs function of circulating blood-derived progenitor cells. Arterioscler Thromb Vasc Biol. 2005;25(4):698703.

66. Chen YH, Lin SJ, Lin FY, Wu TC, Tsao CR, Huang PH, Liu PL, et al. High glucose impairs early and late endothelial progenitor cells by modifying nitric oxide-related but not oxidative stress-mediated mechanisms. Diabetes. 2007;56(6):1559-1568.

67. Aicher A, Heeschen C, Mildner-Rihm C, Urbich C, Ihling C, Technau-Ihling K, Zeiher AM, et al. Essential role of endothelial nitric oxide synthase for mobilization of stem and progenitor cells. Nat Med. 2003;9(11):1370-1376.

68. Segal MS, Shah R, Afzal A, Perrault CM, Chang K, Schuler A, Beem E, et al. Nitric oxide cytoskeletal-induced alterations reverse the endothelial progenitor cell migratory defect associated with diabetes. Diabetes. 2006;55(1):102-109.

69. Chambers SEJ, O'Neill CL, Guduric-Fuchs J, McLoughlin KJ, Liew A, Egan AM, O'Brien T, et al. The Vasoreparative Function of Myeloid Angiogenic Cells Is Impaired in Diabetes Through the Induction of IL1beta. Stem Cells. 2018;36(6):834-843.

70. Sorrentino SA, Bahlmann FH, Besler C, Muller M, Schulz S, Kirchhoff N, Doerries C, et al. Oxidant stress impairs in vivo reendothelialization capacity of endothelial progenitor cells from patients with type 2 diabetes mellitus: restoration by the peroxisome proliferator-activated receptor-gamma agonist rosiglitazone. Circulation. 2007;116(2):163-173.

71. Taljaard M, Ward MR, Kutryk MJ, Courtman DW, Camack NJ, Goodman SG, Parker TG, et al. Rationale and design of Enhanced Angiogenic Cell Therapy in Acute Myocardial Infarction (ENACT-AMI): the first randomized placebo-controlled trial of enhanced progenitor cell therapy for acute myocardial infarction. Am Heart J. 2010;159(3):354-360.

72. Szabo GV, Kovesd Z, Cserepes J, Daroczy J, Belkin M, Acsady G. Peripheral blood-derived autologous stem cell therapy for the treatment of patients with late-stage peripheral artery disease-results of the short- and long-term follow-up. Cytotherapy. 2013;15(10):1245-1252. 